\title{
Aberrant Mucin5B expression in lung adenocarcinomas detected by iTRAQ labeling quantitative proteomics and immunohistochemistry
}

\author{
Yan Li ${ }^{1,3}$, Xiangchun Wang ${ }^{1}$, MingHui Ao ${ }^{1}$, Edward Gabrielson ${ }^{1}$, Frederic Askin ${ }^{1}$, Hui Zhang ${ }^{1}$ and Qing Kay Li ${ }^{1,2^{*}}$
}

\begin{abstract}
Background: Lung cancer is the number one cause of cancer-related deaths in the United States and worldwide. The complex protein changes and/or signature of protein expression in lung cancer, particularly in non-small cell lung cancer (NSCLC) has not been well defined. Although several studies have investigated the protein profile in lung cancers, the knowledge is far from complete. Among early studies, mucin5B (MUC5B) has been suggested to play an important role in the tumor progression. MUC5B is the major gel-forming mucin in the airway. In this study, we investigated the overall protein profile and MUC5B expression in lung adenocarcinomas, the most common type of NSCLCS.

Methods: Lung adenocarcinoma tissue in formalin-fixed paraffin-embedded (FFPE) blocks was collected and microdissected. Peptides from 8 tumors and 8 tumor-matched normal lung tissue were extracted and labeled with 8-channel iTRAQ reagents. The labeled peptides were identified and quantified by LC-MS/MS using an LTQ Orbitrap Velos mass spectrometer. MUC5B expression identified by iTRAQ labeling was further validated using immunohistochemistry (IHC) on tumor tissue microarray (TMA).

Results: A total of 1288 peptides from 210 proteins were identified and quantified in tumor tissues. Twenty-two proteins showed a greater than 1.5-fold differences between tumor and tumor-matched normal lung tissues. Fifteen proteins, including MUC5B, showed significant changes in tumor tissues. The aberrant expression of MUC5B was further identified in $71.1 \%$ of lung adenocarcinomas in the TMA.

Discussions: A subset of tumor-associated proteins was differentially expressed in lung adenocarcinomas. The differential expression of MUC5B in lung adenocarcinomas suggests its role as a potential biomarker in the detection of adenocarcinomas.
\end{abstract}

Keywords: Non-small cell lung cancer, Lung adenocarcinoma, Expression of mucin5B, Quantitative proteomics and iTRAQ labeling, Immunohistochemistry

\section{Introduction}

Lung cancer is the number one cause of cancer-related deaths in the United States and worldwide [1]. Non-small cell lung cancer (NSCLC) accounts for approximately 80$85 \%$ of all lung cancers [1,2]. Among NSCLC subtypes, adenocarcinoma (approximately consisting of 60 to $70 \%$ of

\footnotetext{
* Correspondence: qli23@jhmi.edu

'Department of Pathology, The Johns Hopkins Medical Institutions, Baltimore, MD 21287, USA

2Department of Pathology, The Johns Hopkins Bayview Medical Center, 4940 Eastern Ave., AA Building, Room 154, Baltimore, MD 21224, USA

Full list of author information is available at the end of the article
}

all NSCLC), has been markedly increasing in incidence over recent years [1,2]. Currently, targeted therapies have progressed rapidly, based upon the discovery of novel molecular markers such as mutations in EGFR (epidermal growth factor receptor), KRAS (V-Ki-ras2 Kirsten rat sarcoma viral oncogene homolog) genes and $A L K$ (anaplastic lymphoma kinase) rearrangements [3-5], however, the overall progression-free survival rate of lung cancer patients is still suboptimal [6].

Lung cancer development is a multistep process characterized by genetic alterations and subsequently abnormal

\section{Biomed Central}

(c) 2013 Li et al.; licensee BioMed Central Ltd. This is an open access article distributed under the terms of the Creative Commons Attribution License (http://creativecommons.org/licenses/by/2.0), which permits unrestricted use, distribution, and reproduction in any medium, provided the original work is properly cited. 
expression of cellular proteins $[7,8]$. During the process, cellular proteins, such as those associated with intracellular organelles or located on cell surfaces and secreted into the extracellular environment, play important biological roles in the regulation of cell growth and differentiation. In lung tissue, protein expression directly reflects the physiological and/or pathological status of the lung parenchyma [9-12]. Several recent studies have discovered that many proteins are differentially expressed in lung cancers [13-18]. The complex protein changes and/or signature of protein expression, particularly those associated with NSCLC, still need to be further defined.

Among these potential protein biomarkers, the abnormal expression of mucin proteins in lung cancers is particularly interesting. Mucin proteins are a family of high molecular weight glycoproteins, which are expressed by epithelial cells and/or goblet cells in the airway [19]. Both secretory and membrane-associated mucin proteins play important roles in the regulation of normal lung functions and are involved in many lung diseases $[19,20]$. For example, they are involved in the innate immune defense system of the lung to protect the airway against environmental toxins [19]. The overexpression of mucin proteins has been found in many chronic lung diseases, such as asthma, chronic obstructive pulmonary diseases and cystic fibrosis [19]. Although more than 20 mucin genes and related proteins are identified in human [19-21], the main mucin genes in lung trachoebronchial tree are $M U C 5 B$, $M U C 5 A C$, and MUC4 [21]. An early study of airway mucin gene expression has demonstrated that MUC5 was overexpressed in NSCLCs; and the elevated level of MUC5 was associated with the early recurrence of the tumor and poor prognosis of patients [22]. A recent study has shown that alteration in the expression of MUC1, MUC5AC, and MUC6 are correlated with p53 gene abnormalities in a subtype of lung adenocarcinomas [23]. However, potential role of MUC5B is still not fully understood in lung cancers.

Recent advances in proteomics have provided a novel approach to characterize the protein profile in lung cancer, such as high-content quantitative proteomics using LC-MS/MS (liquid chromatography tandem mass spectrometry) and iTRAQ (isobaric tags for relative and absolute quantitation) labeling [24,25]. These techniques have an increased sensitivity and throughput capability in accurate analysis of biological samples. For example, iTRAQ labeling technique, using stable isotope to label samples, allows for an accurate measurement of the peptide abundance in biological samples by direct comparison of light and heavy peptides in the same spectrum, whereas, the LC-MS/MS method determines the peptide abundance by spectral count based on the number of redundant spectra for each protein. The combination of these techniques could increase the detection of low abundance proteins in biological samples.

In this study, we investigated the protein profiles, including the expression of MUC5B in lung adenocarcinomas using highly sensitive iTRAQ labeling approach, and further validate our observations by immunohistochemistry (IHC) using lung adenocarcinoma tissue microarray (TMA). The purpose of our study is to investigate the expression of tumor-associated proteins and their potential roles in lung adenocarcinomas.

\section{Material and methods \\ Materials}

Sodium periodate (Bio-Rad, Hercules, CA), Tris (2-carboxyethyl) phosphine (TCEP) (Pierce, Rockford IL), sequencing grade trypsin (Promega, Madison, WI), C18 columns (Waters, Sep-Pak Vac), $\alpha$-cyano-4-hydroxycinnasmic acid (CHCA) (Agilent, Palo Alto, CA), MALDI 4700 mass calibration standards (Applied Biosystems, Foster City, CA), and other chemicals were purchased from Sigma-Aldrich. iTRAQ reagent and mass calibration standards were from Applied Biosystems (Foster City, CA); BCA assay kit was from Pierce (Rockford, IL); SCX columns and C18 resin were from Sepax (Newark, DE).

\section{Lung cancer sample collection and tumor tissue microarray (TMA) construction}

Eight lung adenocarcinomas, including four cases each of pathological stage 1 (pT1) and stage2 (pT2) tumors, and 8 cases of tumor-matched normal lung tissues were obtained from surgical resected specimens at the Johns Hopkins Hospital. All tumors and tumor-matched normal lung tissues were fixed in formalin and embedded in paraffin prior to proteomic analysis.

Tumor tissue microarrays (TMA) were constructed with independently collected 45 cases of lung adenocarcinomas. Represented on arrays were 24 cases of pT1, 18 cases of pT2, two cases of pT3 and one case of pT4 tumors. The TMA was prepared using core samples $(1 \mathrm{~mm}$ diameter, 3 cores per case) of paraffin tissue blocks. The pathological stage and subtype of lung adenocarcinomas were classified according to AJCC (American Joint Committee on Cancer) staging manual [26], WHO (World Health Organization) and International Association for the Study of Lung Cancer/American Thoracic Society classification $[2,27]$. All tumor samples were annotated with available clinical information in a manner that protected the patient identity.

\section{Protein and peptide extraction from tumor tissue for proteomic analysis}

For proteomic analysis, the formalin-fixed paraffinembedded (FFPE) tumor tissue and tumor-matched normal lung tissue were cut into 10 micron section and 
placed on a glass slide without staining prior to microdissection and protein extraction.

To recover protein, hydration step was performed. The tumor tissue section on glass slide was incubated with $x y-$ lene for $15 \mathrm{~min}$ twice, 100\% ethanol for $5 \mathrm{~min}, 90 \%$ ethanol for $5 \mathrm{~min}, 80 \%$ ethanol for $5 \mathrm{~min}$, then rinsed with distill $\mathrm{H}_{2} \mathrm{O}$ for 30 second twice. The rehydrated tumor tissue was microdissected and collected into a centrifuge vial with $25 \mu \mathrm{l}$ of PBS buffer. Tumor tissue was sonicated for $5 \mathrm{~min}$ on an ice bath and centrifuged at 13,200 rpm for $5 \mathrm{~min}$. The protein concentration in the supernatant was measured using BCA protein assay kit (Thermo Fisher Scientific Inc., Rockford, Illinois). For protein digestion, $10 \mu \mathrm{g}$ of proteins (20 $\mu \mathrm{l}$ in volume) was first denatured in $90 \mu \mathrm{l}$ of $8 \mathrm{M}$ urea, $0.4 \mathrm{M} \mathrm{NH} 4 \mathrm{HCO} 3$, and $0.1 \%$ SDS for 1 hour at $60^{\circ} \mathrm{C}$. The proteins were then reduced by incubating with $10 \mu \mathrm{l}$ of $120 \mathrm{mM}$ Tris(2-carboxyethyl) phosphine for $30 \mathrm{~min}$ and alkylated by mixing with $10 \mu \mathrm{l}$ of $160 \mathrm{mM}$ iodoacetamide at room temperature for $30 \mathrm{~min}$ in the dark. Sample was diluted by $200 \mu \mathrm{l}$ of trypsin digestion buffer (100 mM Tris- $\mathrm{HCl}, \mathrm{pH} 7.5)$ containing $2 \mu \mathrm{g}$ of trypsin at $37^{\circ} \mathrm{C}$ overnight. The digested peptides were purified with C18 desalting columns and dried using SpeedVac.

\section{ITRAQ labeling of peptides in lung adenocarcinoma}

The iTRAQ (isobaric tags for relative and absolute quantitation) 8-plex reagent was dissolved in $70 \mu \mathrm{l}$ of methanol. $10 \mu \mathrm{g}$ of tryptic peptide of each sample was added into $20 \mu \mathrm{l}$ of iTRAQ dissolution buffer, then mixed with $70 \mu \mathrm{l}$ of iTRAQ 8-plex reagent and incubated for 1 hour at room temperature. After iTRAQ labeling, the reaction solution was cleaned up by SCX column. Then, labeled peptides were dried and resuspended into $10 \mu \mathrm{l}$ of $0.4 \%$ acetic acid solution prior to mass spectrometry analysis.

\section{Mass spectrometry analysis}

For protein quantification by spectral count, each peptide mixture was analyzed using LC-MS/MS (liquid chromatography tandem mass spectrometry) by the LTQ ion trap mass spectrometer (Thermo Finnigan, San Jose, CA). During the assay, $10 \mu \mathrm{l}(10 \mu \mathrm{g})$ peptides were injected into a peptide cartridge packed with $\mathrm{C} 18$ resin, and then passed through a $10 \mathrm{~cm} \times 75 \mu \mathrm{m}$ i.d. microcapillary HPLC $(\mu \mathrm{LC})$ column packed with $\mathrm{C} 18$ resin. The effluent from the $\mu \mathrm{LC}$ column entered an electrospray ionization source in which peptides were ionized and passed directly into the mass spectrometers. A linear gradient of acetonitrile from 5\%$32 \%$ over $100 \mathrm{~min}$ at flow rate of approximately $300 \mathrm{~nL} /$ min was applied. During the LC-MS mode, data was acquired in the $m / z$ range of 400 and 2000 .

Mass spectrometry analysis was performed using a data dependent analysis of the top ten precursors and a dynamic exclusion of 30 seconds. The data was acquired at
30,000 resolution for the precursor scans and 7500 for MS/MS. Target values of $1 \mathrm{e} 6$ for MS and $1 \mathrm{e} 5$ for MS/ MS were set with maximum injection time of 100 and 300 milliseconds, respectively. Data was acquired with Monoisotopic Precursor Selection (MIPS) and Predictive AGC enabled.

\section{Analysis of iTRAQ labeled peptides using HPLC-Orbitrap-MS platform}

iTRAQ labeled peptide was analysed in the same setting as described above. Peptides identification by LC-MS was performed using an Orbitrap MS/MS (Thermo Fisher Scientific Inc., Rockford, Illinois) interfaced with a 2D nanoLCsystem (Eksigent, Dublin, California). $10 \mu \mathrm{l}$ of pooled peptides $(10 \mu \mathrm{g})$ were loaded on a self packed C18 column $(75 \mu \mathrm{m}$ ID $\times 10 \mathrm{~cm}$, Magic C18 $5 \mu \mathrm{m}$, 100A), and gradient eluted over 100 minutes at $300 \mathrm{~nL} /$ minute into the mass spectrometer. The HPLC mobile phase $\mathrm{A}$ and $\mathrm{B}$ were $0.2 \%$ formic acid in HPLC grade water and $0.2 \%$ formic acid in HPLC grade acetonitrile, respectively. The mobile phase $\mathrm{B}$ was increased from $5 \%$ to $40 \%$ in $90 \mathrm{~min}$.

\section{Peptide identifications}

The acquired data was searched against the Homo sapiens taxonomy of the RefSeq database (Version 40, 04/16/ 2010) using the Mascot (Matrix Science version 2.2.0) search algorithm within Proteome Discoverer (Thermo Scientific version 1.1). The data was searched with two missed cleavages allowed and a tolerance of $15 \mathrm{ppm}$ on the precursors and 0.02 daltons on the fragment ions. Modifications allowed included carbamidomethyl of cysteines set to static. Data was also searched against a decoy database and filtered to a $1 \%$ false discovery rate (FDR).

\section{Immunohistochemistry (IHC)}

IHC studies were performed using two lung adenocarcinoma TMAs. The sections were cut at 4 microns and deparaffinized prior to performing IHC. After treatment with antigen retrieval buffer (Dako, California) at $70^{\circ} \mathrm{C}$ for 40 minutes, slides were incubated with mouse monoclonal antibody anti-human MUC5B (clone 19.4E) at 1:200 dilutions for $1 \mathrm{hr}$. (Abcam, Cambridge, Massachusetts). After washing, a secondary antibody conjugated with peroxidase was applied to detect and visualize the specific antigenantibody complexes using LASB System-HRP assay kit (Dako, California). Staining of MUC5B was scored semiquantitatively using a four tier system: 0 , undetectable $(0 \%$ positive cells); $1+$, focally positive ( $<10 \%$ positive cells); $2+$, moderately positive ( $<50 \%$ positive cells), and $3+$, intensely positive (more than $50 \%$ positive cells). Care was taken not to interpret entrapped normal bronchial epithelium or pulmonary macrophages as positive for tumor staining. Appropriate controls were also included in the assay. 
Chi-square and Fisher's test were used to calculate the $p$ value. If the alpha value was less than 0.05 , it was considered statistically significant $(p<0.05)$.

\section{Results}

\section{Clinical information}

A total of eight adenocarcinoma and tumor-matched normal control lung tissues were used for the proteomic analysis. The clinical information of these cases was summarized in Table 1. On lung adenocarcinoma TMA, a total of 45 cases were included. The subtypes of tumors were as follows: adenocarcinoma with papillary features (16 cases), adenocarcinoma NOS (13 cases), mucinous adenocarcinoma (6 cases), true papillary adenocarcinoma (6 cases) [28] and non-mucinous adenocarcinoma with lepidic pattern (formerly bronchioloalveolar adenocarcinoma, 4 cases). The representative morphology of a lung adenocarcinoma is shown in the Figure 1. In our study, the patients' age ranged from 48 to 83 years with a median of 66.5 years. The male to female ratio was 1:1.37 (19 males and 26 females). $71.1 \%$ patients (32 of 45 cases) were current or ex-smokers. The average size of tumors was $3.56 \mathrm{~cm}$ (range from 0.7 to $12 \mathrm{~cm}$ ).

\section{Protein identification and profile in lung adenocarcinoma tissues}

The quantitative proteomic analyses are schematically illustrated in Figure 2 and consist of following steps: (1) tumor tissues were microdissected and proteins were extracted; (2) total proteins were further digested into peptides; (3) the peptides were labeled with 8-plex iTRAQ reagents; and (4) peptides were identified and quantified by LC-MS/MS, and spectral count. Peptides from four cases of pT1 tumor cases were labeled with iTRAQ channel 117, 118, 119, 120, while peptides from pT2 tumor cases were labeled with channel 113, 114, 115, and 116. The quantitative results were generated from the peak area of MS2 peaks of fragments (m/z from 113 to 121) of iTRAQ reagents. The LC-MS/MS method determines the peptide abundance by comparing the intensity of the same peptide peak in multiple LC-MS/MS runs. Quantitation of protein abundance by spectral count is based on the number of redundant spectra acquired for each protein from different samples in the LC-MS/MS analyses. We were able to identify and quantify 210 proteins using iTRAQ labeling [29].

We then determined and quantified the protein changes in different stage of tumors by iTRAQ. To determine the proteins with abundance changes in two stages, a histogram was used to generate the number of proteins in different abundance ratio. The threshold was set as $<0.7$ and $>1.3$ for iTRAQ labeling. The means of pT1 and pT2 samples were used and the ratio of the means of pT1 to pT2 was calculated. Most of proteins (188 proteins, $89.5 \%$ ) were distributed within one standard deviation from the mean and were considered as unchanged. Proteins that fell out of one standard deviation of the distribution curve were considered as with significant changes. A total of 22 proteins were identified between pT1 and pT2 tumors. These proteins were summarized in the Table 2 .

\section{Further identification and quantitative analysis of MUC5B in tumor tissue}

We further analyzed the level of MUC5B in different stages of tumors and tumor-matched normal lung tissues using LC-MS/MS spectrum counts (Figure 3 and Figure 4). Our data demonstrated that the abundance of MUC5B in tumor tissue was significantly more than that in tumormatched normal tissue regardless of tumor stages.

To evaluate expression and cellular localization of MUC5B protein in lung adenocarcinoma tissues, we performed IHC using mouse anti-MUC5B monoclonal antibody (clone19.4E), which reacts with MUC5B and does not react with MUC5A or MUC5C. The overall expression of MUC5B in 45 lung adenocarcinoma tumors is summarized in Figure 5 and Table 3. Of 45 tumors, 13 cases $(28.9 \%)$ were negative for MUC5B expression, 8 cases (17.8\%) were weakly positive, 13 cases (28.9\%) and 11 cases $(24.4 \%)$ were focally and intensely positive. The

Table 1 Clinical characterization of lung adenocarcinomas

\begin{tabular}{|c|c|c|c|c|c|c|}
\hline Cases & Age (years) & Sex & $\mathrm{T}$ size $(\mathrm{cm})$ & T stage & Location of tumor & Surgery \\
\hline 1 & 67 & $M$ & 2.4 & pT1 & RLL & Lobectomy \\
\hline 2 & 69 & $\mathrm{~F}$ & 1.5 & pT1 & RUL & Wedge resection \\
\hline 3 & 82 & $M$ & 1.8 & pT1 & LUL & Lobectomy \\
\hline 4 & 55 & $\mathrm{~F}$ & 1.5 & pT1 & RLL & Lobectomy \\
\hline 5 & 67 & $M$ & 12.0 & pT2 & LLL & Lobectomy \\
\hline 6 & 64 & $\mathrm{~F}$ & 9.0 & pT2 & RLL & Lobectomy \\
\hline 7 & 78 & $\mathrm{~F}$ & 4.0 & pT2 & RUL & Lobectomy \\
\hline 8 & 77 & M & 2.5 & pT2 & LLL & Lobectomy \\
\hline
\end{tabular}

T: Tumor. $p T$ : Pathological stage of tumor. R: Right. L: Left or lower or lobe. U: Upper. 


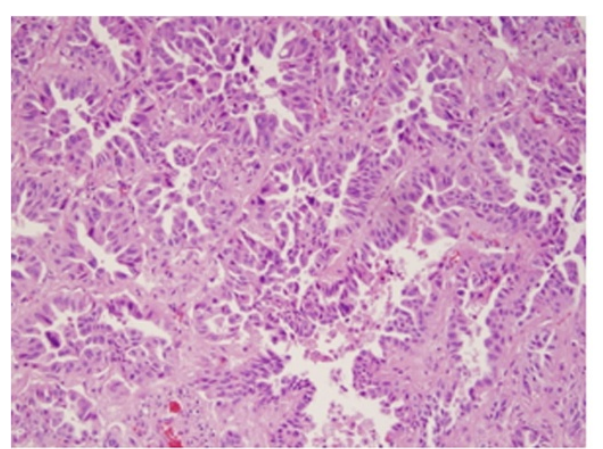

Adenocarcinoma

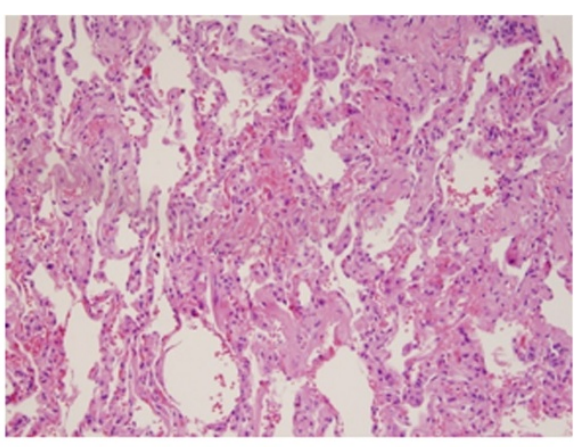

Tumor-matched Normal lung

Figure 1 Histomorphology of lung adenocarcinomas.

predominant location of MUC5B in tumor cells was in the cytoplasmic membrane. Among different subtypes of adenocarcinomas, MUC5B was detected in 25\% (1 of 4 cases) of adenocarcinomas with lepidic patterns, $62.5 \%$ (10 of 16 cases) of adenocarcinoms with papillary features, $66.7 \%$ ( 4 of 6 cases) of true papillary adenocarcinomas, $84.6 \%$ (11 of 13 cases) of adenocarcinomas NOS, and 100\% (6 of 6 cases) of mucinous adenocarcinomas. In normal lung parenchyma, alveolar macrophages showed some cytoplasmic staining of MUC5B.

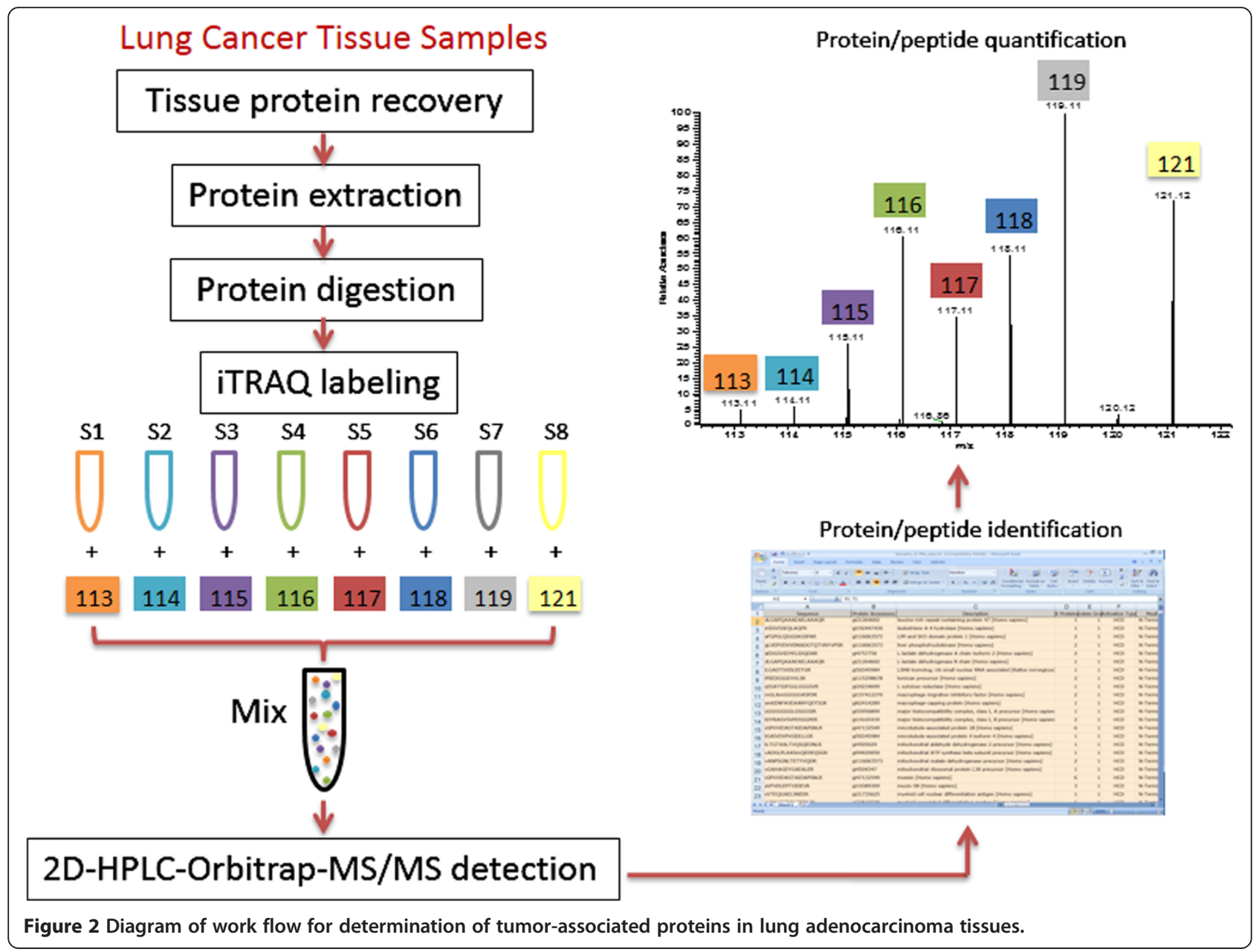


Table 2 Proteins with differential expression in lung adenocarcinomas

\begin{tabular}{|c|c|c|c|c|}
\hline Accession & Proteins & MW [kDa] & Coverage & Ratio of $\mathrm{T} 2 / \mathrm{T} 1$ tumor \\
\hline gi52426774 & MHC, class II, DR alpha & 28.6 & 5.51 & 3.109794973 \\
\hline gi110611233 & Alpha 1 type XVIII collagen isoform 2 & 135.4 & 1.27 & 2.876066498 \\
\hline gi4504347 & Hemoglobin subunit alpha & 15.2 & 15.49 & 2.672828838 \\
\hline gi169217452 & HLA class II histocompatibility antigen, DRB1-4 beta chain & 25.7 & 8.97 & 2.548467326 \\
\hline gi56682959 & Ferritin heavy chain & 21.2 & 5.46 & 2.376697349 \\
\hline gi66346695 & Fibrillin-2 & 314.6 & 0.24 & 2.288948591 \\
\hline gi40786436 & Eukaryotic translation initiation factor $4 \mathrm{~A} 1$ & 46.1 & 2.46 & 2.094114969 \\
\hline gi87196339 & Collagen, type VI, alpha 1 & 108.5 & 0.88 & 1.986732711 \\
\hline gi4557733 & Latent transforming growth factor beta binding protein 2 & 194.9 & 4.17 & 1.959638153 \\
\hline gi169210992 & Hypothetical protein LOC100131693 & 25.1 & 3.69 & 1.909014562 \\
\hline gi24797076 & MHC, class II, DR beta 1 & 29.1 & 3.49 & 1.879322964 \\
\hline gi207028935 & Microfibrillar-associated protein 2 isoform b & 20.7 & 5.49 & 1.846061192 \\
\hline gi4502107 & Annexin A5 & 35.9 & 6.25 & 1.785327852 \\
\hline gi53946395 & Tenascin & 240.7 & 2.04 & 1.758381294 \\
\hline gi4758606 & Integrin-linked protein kinase & 51.4 & 2.43 & 1.673110304 \\
\hline gi13775595 & Tryptase alpha/beta 1 & 30.5 & 6.55 & 1.638626466 \\
\hline gi5453678 & Epididymal secretory protein E1 & 16.6 & 10.60 & 1.515388592 \\
\hline gi4557759 & Myeloperoxidase & 83.8 & 1.34 & 0.557022924 \\
\hline gi28827801 & Anterior gradient protein 3 & 19.2 & 6.63 & 0.475747013 \\
\hline gi54607120 & Lactotransferrin & 78.1 & 1.27 & 0.334947079 \\
\hline gi124248516 & Alpha-defensin 1 & 10.2 & 19.15 & 0.272535866 \\
\hline gi53945878 & Mucin-5B & 596.3 & 1.11 & 0.246384026 \\
\hline
\end{tabular}

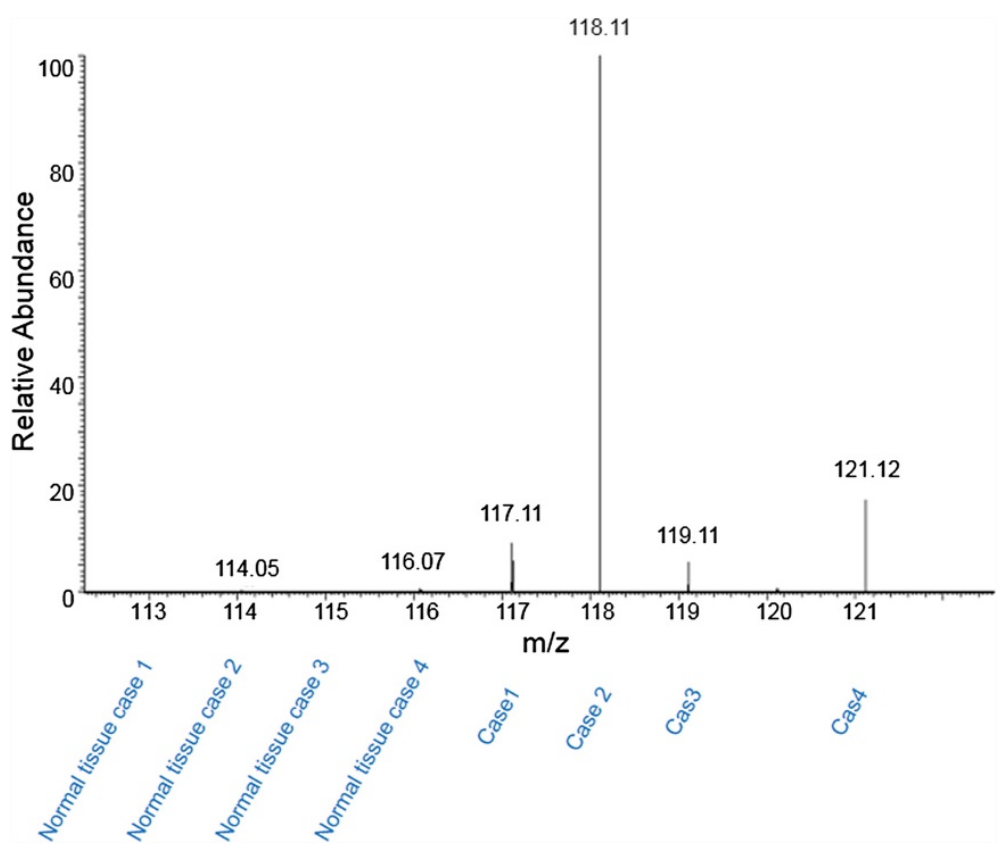

Figure 3 MS spectrum of mucin5B in pT1 lung adenocarcinomas and tumor-matched normal lung tissues. 


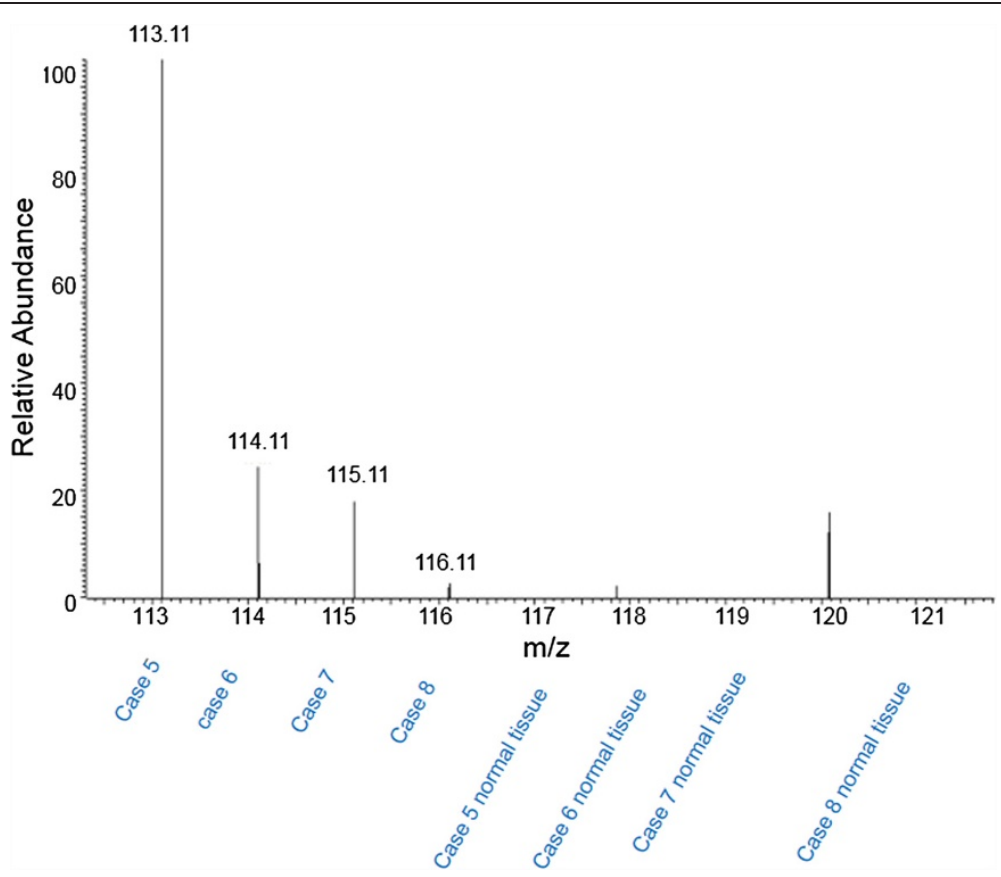

Figure 4 MS spectrum of mucin5B in pT2 lung adenocarcinomas and tumor-matched normal lung tissues.

\section{Discussion}

The lung parenchyma and alveolar space are complex structures that contain numerous cellular proteins. In addition, lung cancer involves numerous genetic abnormalities with turn-on and turn-off expression at different stage of the tumor. In our study, in order to increase the detection of tumor associated proteins, different pathological stages of tumor tissues were included. Using the iTRAQ labeling approach, a total of 1288 peptides from 210 proteins were identified and quatified. Among them,
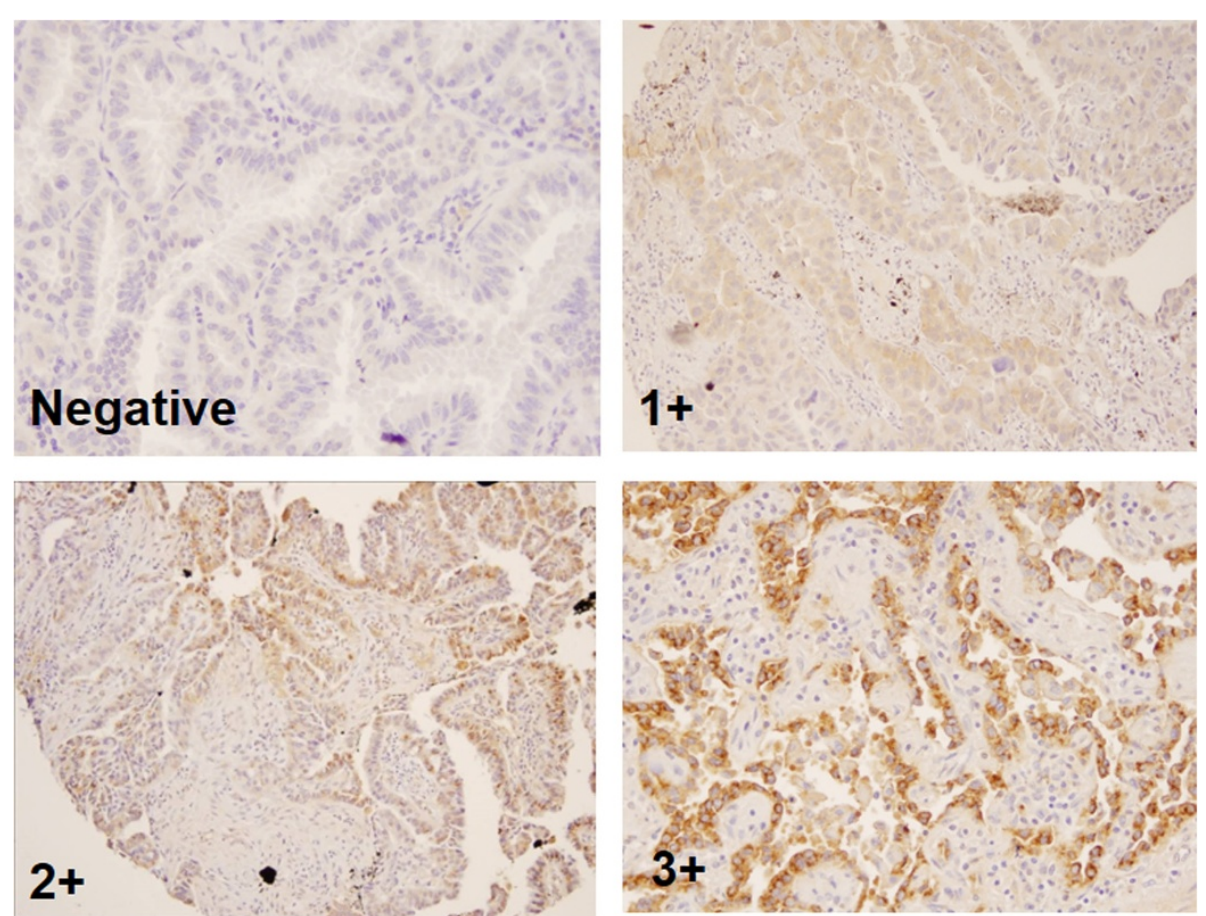

Figure 5 Immunostain of mucin 5B in lung adenocarcinomas. 


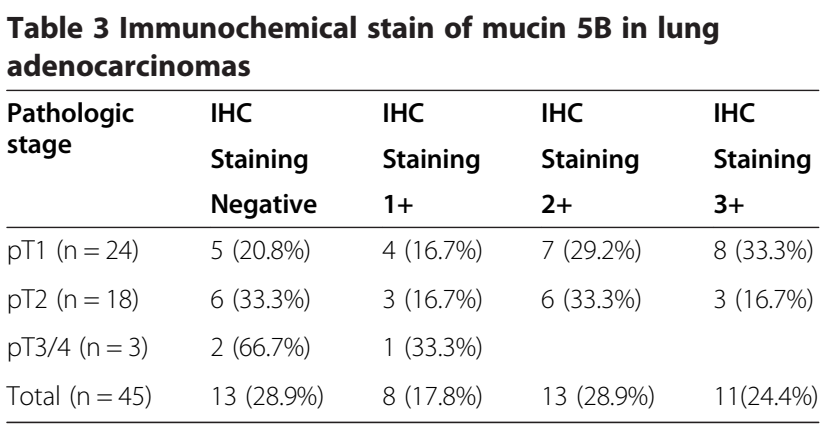

22 proteins showed greater than 1.5 -fold differences between stage pT1 and pT2 tumors. A subset of proteins, such as fibrillin-2, ferritin, eukaryotic translation initiation factor 4A1 (eIF-4A1), annexin A5, mucin-5B (MUC5B), alpha-defensin 1 and anterior gradient protein 3 (hAG 3), are interesting.

In our study, the detection of MUC5B in tumor tissue is particularly interesting. Mucins (MUC) are a family of high molecular weight, heavily glycosylated proteins. In human, more than 20 mucin genes and related proteins are identified [19-21]. They can be divided into two major groups, membrane-associated mucin proteins including MUC1, MUC3, MUC4, MUC12, MUC13, MUC16 and MUC17; and secreted mucin proteins including both gelforming such as MUC2, MUC5AC, MUC5B, MUC6 proteins, and non-gel-forming MUC7 protein [19-21]. Both types of mucins play important roles in the regulation of cellular functions such as formation of physical barrier, maintenance homeostasis of extracellular environment, and regulation of cell growth and differentiation. In cancer cells, mucin proteins also play important roles in tumor cell growth, invasion and metastasis [20]. Overexpression of MUC1 has been associated with potential risk of metastasis of colon cancer [30], pancreatic cancer [31] and oral squamous cell carcinoma [32]. The expression of MUC2 has been identified in pancreatic and liver cancer [33]. MUC4 protein contains an EGF (epidermal growth factor)-like motif on the extracellular domain and has been linked to the EGF signaling pathway $[34,35]$. It has been reported that main mucin genes in lung trachoebronchial tree are $M U C 5 B, M U C 5 A C$, and MUC4 [21]. Among them, MUC5B is the major gel-forming mucin which forms a protective matrix in the airway. In normal adult lung parenchyma, the expression of MUC5B follows a distinct pattern. It is predominately expressed in the mucus producing cells in the large airway; the intensity of its expression is decreased from tracheobronchus towards the bronchioles, with no expression in small bronchioles and pneumocytes [36]. A few recent studies have shown that MUC5B is also frequently expressed in lung mucinous adenocarcinoma, and the expression of MUC5B is inversely correlated with the differentiation of the tumor [37]. Abnormal expressions of MUC1, MUC5 and MUC6 have also been related to the aggressive behavior of lung adenocarcinoma [22,23,38]. In our study, we found elevated expression of MUC5B in lung adenocarcinoma by iTRAQ labeling and further validated by IHC using lung adenocarcinoma TMAs. In the iTRAQ labeling study, it seems that there is a loss of MUC5B expression in higher stage of tumors (stage II lung adenocarcinomas), however, we will not be able to draw a conclusion due to a small set of cases in our study. We further performed an IHC assay using mouse anti-MUC5B monoclonal antibody (clone19.4E) to evaluate the expression of MUC5B using TMA. The monoclonal antibody in our study reacts with MUC5B, but does not react with MUC5A or MUC5C. We found that the expression of MUC5B was detected in 32 of 45 tumors (71.1\%). Of 32 tumors, 8 cases (17.8\%) were weakly positive, 13 cases $(28.9 \%)$ and 11 cases (24.4\%) were focally and intensely positive. The predominant location of MUC5B in tumor cells was in the cytoplasmic membrane. Among different subtypes of adenocarcinomas, MUC5B was detected in 25\% (1 of 4 cases) of adenocarcinomas with lepidic patterns, $62.5 \%$ (10 of 16 cases) of adenocarcinoms with papillary features, $66.7 \%$ ( 4 of 6 cases) of true papillary adenocarcinomas, $84.6 \%$ (11 of 13 cases) of adenocarcinomas NOS, and 100\% (6 of 6 cases) of mucinous adenocarcinomas. Our data demonstrates that MUC5B is abnormally expressed by most of tumors, and suggests that it may be a potential biomarker for lung adenocarcinomas.

Furthermore, we also found several proteins were differentially expressed in tumors, such as fibrillin-2, ferritin, hypothetical protein LOC100131693, eIF4A, annexin A5, anterior gradient-2 (hAG-2) and alpha-defensin-1. Fibrillin2 is the key component of human elastic fiber in extracellular matrix. Aberrant methylation of its gene has been found in $53 \%$ of lung adenocarcinoms and has been correlated with large tumor size, nodal metastasis and advanced tumor stage in NSCLC [39]. Ferritin is an iron-binding protein; elevated serum level has been detected in advanced lung cancer patients, overexpression of this protein has been found in tumor tissue and has been reported to correlate with nodal metastasis in NSCLC [40]. Hypothetical protein LOC100131693 belongs to a group of proteins that are not described at the protein level but rather predicted from cDNA sequences [41]. It is of special interest as it may represent a new marker or marker for development of tumor vaccine, particularly when found in tumor tissue. eIF4A plays an important role in the regulation of eIF4E-eIF4G complex during the eukaryotic translation initiation in the AKT-mTOR signal pathway, which involves cell growth, angiogenesis, invasion, survival [42]. Annexin A5 is a phospholipid binding protein and binds to phophatidylserine. During early events of apoptosis, annexin A5 binds to phosphatidylserine on the cell membrane, thus regulates programmed cell death. It has been found to be overexpressed in $\mathrm{p}$-XSC treated mice lung adenocarcinoma [43]. Interestingly, the use of isotopic 
labeled annexin A5 as a clinical tool for visualization of cell death has been suggested to be important in monitoring patient's response to chemotherapy [44]. The human anterior gradient-2 (hAG-2) gene has been proposed an oncogene for NSCLC. The hAG-2 is expressed in lung squamous cell carcinoma [45]. In the screening of breast tumor tissue using reverse transcription-PCR and immunohistochemistry with affinity purified anti-hAG-2 antibodies, Liu et al. reported that the presence of hAG-2 mRNA and protein were associated with estrogen alpha (ERA)-positive carcinomas [46]. There were no differences in the mean latency periods of tumor formation when an expression vector bearing hAG-2 cDNA was introduced into benign rat mammary tumor cells, but metastases occurred at high rates in the lung of animals receiving the hAG-2 transfectants (77-92\% of animals with primary tumors, compared with $0 \%$ in the control groups). Their results suggest that hAG-2 may be a potential marker related to cancer metastasis. Alphadefensin-1, also known as the human neutrophil peptides (HNP1-3), is a small cationic peptide found in neutrophil granules. Alpha-defensin showed cytotoxicity to various types of eukaryotic and tumor cells. The mechanism of alpha-defensin induced cell damage and death involves release of cytochrome c from mitochondria, which is the key event of mitochondria-mediated apoptosis; it has been found to inhibit the growth of human lung adenocarcinoma xenograft in nude mice [47]. The Biological role of these proteins in lung adenocarcinomas need to be further investigated.

A recent study by Kikuchi $\mathrm{T}$, et al [48] has shown that 3513 proteins were identified from pooled lung adenocarcinoma tissues using the shotgun proteomic method, and they further validate a few candidate proteins using multiple reactions monitoring MS, IHC staining and Western blotting analysis. In comparison to their study, we have also identified similar proteins in tumor tissues using iTRAQ labeling approach, such as eIF, collagen type VI, tenascin, anterior gradient protein, MUC5B, and hemoglobin subunit alpha BAL. In our recent study of lung airway fluid, we have further identified a subset of proteins derived from tumor tissue in the airway fluid specimens [29]. Taken together, these findings are important and suggest that unique tumor-derived proteins can be identified in both lung parenchyma and airway fluid, and some of these proteins could be further tested and validated as potential biomarkers for the detection of lung adenocarcinomas.

In summary, our data demonstrate that a large number of protein changes during the lung cancer disease process can be identified by quantitative proteomic approaches. However, the potential role of these identified proteins need to be further validated and characterized. The study of protein expression in lung cancers is also important for understanding the disease process, assessing the tumor progression, and customizing therapeutic modalities for individual patients.

\section{Consent}

The use of human tumor tissues and related pathological information was approved by the Johns Hopkins Institutional Review Board.

\section{Competing interests}

The authors declare that they have no competing interests.

\section{Authors' contributions}

$Y L$ carried out the MS study and analyzed data, and wrote the manuscript, $\mathrm{XW}$ and $\mathrm{MH}$ Ao performed $\mathrm{IHC}$ studies and analyzed data, EG, FA and $\mathrm{HZ}$ provided critical supports for the study and critics for the manuscript. QKL wrote and was responsible for the manuscript. All authors read and approved the final manuscript.

\section{Acknowledgement}

This work is partially supported by United States Department of Defense grant PC081386 (YL), Drs. Ji \& Li Family Cancer Research Foundation (QKL) and by National Cancer Institute, The Early Detection Research Network (EDRN grant U01CA152813) and The Clinical Proteomic Tumor Analysis Consortium (CPTAC U24CA160036) (HZ).

\section{Author details}

'Department of Pathology, The Johns Hopkins Medical Institutions, Baltimore, MD 21287, USA. ²Department of Pathology, The Johns Hopkins Bayview Medical Center, 4940 Eastern Ave., AA Building, Room 154, Baltimore, MD 21224, USA. ${ }^{3}$ Current address: Institute of Biophysics, Room 9214, 15 Datun Road, Room 9214, Chanyang, Beijing 100101, P. R. China.

Received: 2 April 2013 Accepted: 17 September 2013 Published: 1 November 2013

\section{References}

1. Siegel R, Naishadham D, Jemal A: Cancer statistics, 2012. CA Cancer J Clin. 2012, 62:10-29.

2. Parkin M, Tyczynski JE, Boffetta P, Samet J, Shields P, Brambilla E, Caporaso N, Tumours of the lung, Travis WD, Muller-Hermelink HK, Harris CC (Eds): WHO classification of tumours. Pathology and genetics of tumours of the lung, pleura, thymus and heart. Lyon: IARC press; 2004:p9-124.

3. Lynch TJ, Bell DW, Sordella R, Gurubhagavatula S, Okimoto RA, Brannigan BW, Harris PL, Haserlat SM, Supko JG, Haluska FG, Louis DN, Christiani DC, Settleman J, Haber DA: Activating mutations in the epidermal growth factor receptor underlying responsiveness of non-small cell lung cancer to gefitinib. N Engl J Med. 2004, 350:2129-2139.

4. Paez JG, Jänne PA, Lee JC, Tracy S, Greulich H, Gabriel S, Herman P, Kaye FJ, Lindeman N, Boggon TJ, Naoki K, Sasaki H, Fujii Y, Eck MJ, Sellers WR, Johnson BE, Meyerson M: EGFR mutations in lung cancer: correlation with clinical response to gefitinib therapy. Science. 2004, 304:1497-1500.

5. Janku F, Garrido-Laguna I, Petruzelka LB, Stewart DJ, Kurzrock R: Novel therapeutic targets in non-small cell lung cancer. J Thorac Oncol 2011, 6:1601-1612. Review.

6. National Lung Screening Trial Research Team, Aberle DR, Adams AM, Berg CD, Black WC, Clapp JD, Fagerstrom RM, Gareen IF, Gatsonis C, Marcus PM, Sicks JD: Reduced lung-cancer mortality with low-dose computed tomographic screening. N Engl J Med 2011, 365:395-409.

7. Beroukhim R, Mermel CH, Porter D, Wei G, Raychaudhuri S, Donovan J, Barretina J, Boehm JS, Dobson J, Urashima M, Mc Henry KT, Pinchback RM, Ligon AH, Cho YJ, Haery L, Greulich H, Reich M, Winckler W, Lawrence MS, Weir BA, Tanaka KE, Chiang DY, Bass AJ, Loo A, Hoffman C, Prensner J, Liefeld T, Gao Q, Yecies D, Signoretti S, et al: The landscape of somatic copy-number alteration across human cancers. Nature. 2010, 463:899-905.

8. Anagnostou VK, Dimou AT, Botsis T, Killiam EJ, Gustavson MD, Homer RJ, Boffa D, Zolota V, Dougenis D, Tanoue L, Gettinger SN, Detterbeck FC, Syrigos KN, Bepler G, Rimm DL: Molecular classification of nonsmall cell lung cancer using a 4-protein quantitative assay. Cancer 2012, 118:1607-1618.

9. Chen G, Gharib TG, Wang H, Huang CC, Kuick R, Thomas DG, Shedden KA, Misek DE, Taylor JM, Giordano TJ, Kardia SL, lannettoni MD, Yee J, Hogg PJ, Orringer MB, Hanash SM, Beer DG: Protein profiles associated with survival in lung adenocarcinoma. Proc Natl Acad Sci U S A. 2003, 100:13537-13542. 
10. Nambu Y, Beer DG: Altered surface markers in lung cancer. Lack of cellsurface Fas/APO-1 expression in pulmonary adenocarcinoma may allow escape from immune surveillance. Methods Mol Med. 2003, 74:259-266.

11. Tian T, Hao J, Xu A, Luo C, Liu C, Huang L, et al: Determination of metastasis-associated proteins in non-small cell lung cancer by comparative proteomic analysis. Cancer Sci 2007, 98:1265-1274.

12. Poletti V, Poletti G, Murer B, Saragoni L, Chilosi M: Bronchoalveolar lavage in malignancy. Semin Respir Crit Care Med. 2007, 28:534-545.

13. Yanagisawa K, Shyr Y, Xu BJ, Massion PP, Larsen PH, White BC, Roberts JR, Edgerton M, Gonzalez A, Nadaf S, Moore JH, Caprioli RM, Carbone DP: Proteomic patterns of tumour subsets in non-small-cell lung cancer. Lancet 2003, 362:433-439.

14. Kawamura T, Nomura M, Tojo H, Fujii K, Hamasaki H, Mikami S, Bando Y, Kato H, Nishimura T: Proteomic analysis of laser-microdissected paraffin-embedded tissues: (1) stage-related protein candidates upon non-metastatic lung adenocarcinoma. J Proteomics. 2010, 73:1089-1099.

15. Nishimura T, Nomura M, Tojo H, Hamasaki H, Fukuda T, Fujii K, Mikami S, Bando $Y$, Kato $\mathrm{H}$ : Proteomic analysis of laser-microdissected paraffin-embedded tissues: (2) MRM assay for stage-related proteins upon non-metastatic lung adenocarcinoma. J Proteomics. 2010, 73:1100-1110.

16. Chen G, Gharib TG, Huang CC, Thomas DG, Shedden KA, Taylor JM, Kardia SL, Misek DE, Giordano TJ, lannettoni MD, Orringer MB, Hanash SM, Beer DG: Proteomic analysis of lung adenocarcinoma: identification of a highly expressed set of proteins in tumors. Clin Cancer Res. 2002, 8:2298-2305.

17. Li QK, Gabrielson E, Zhang H: Application of glycoproteomics in the discovery of biomarkers for lung cancer. Proteomics: Clinical App. 2012, 5-6:244-256.

18. Li QK, Gabrielson E, Askin F, Chan DW, Zhang H: Glycoproteomics using fluid based specimens in the discovery of lung cancer protein biomarkers. Promise and challenge. Proteomics Clinical App. 2013, 7:55-69.

19. Ross MC, Voynow JA: Respiratory tract mucin genes and mucin glycoproteins in health and disease. Physiol Rev. 2006, 86:245-278.

20. Hollingsworth MA, Swanson BJ: Mucins in cancer: protection and control of the cell surface. Nature Rev Cancer. 2004, 4:45-60.

21. Dekker J, Rossen JW, Büller HA, Einerhand AW: The MUC family: an obituary. Trends Biochem Sci. 2002, 27:126-131.

22. Yu CJ, Yang PC, Shun CT, Lee YC, Kuo SH, Luh KT: Overexpression of MUC5 genes is associated with early post-operative metastasis in non-small-cell lung cancer. Int J Cancer. 1996, 69:457-465.

23. Awaya H, Takeshima Y, Yamasaki M, Inai K: Expression of MUC1, MUC2, MUC5AC, and MUC6 in atypical adenomatous hyperplasia, bronchioloalveolar carcinoma, adenocarcinoma with mixed subtypes, and mucinous bronchioloalveolar carcinoma of the lung. Am J Clin Pathol. 2004, 121:644-653.

24. Zhang H, Li XJ, Martin DB, Aebersold R: Identification and quantification of $\mathrm{N}$-linked glycoproteins using hydrazide chemistry, stable isotope labeling and mass spectrometry. Nat Biotechnol. 2003, 21:660-666.

25. Tian Y, Tan AC, Sun X, Olson MT, Xie Z, Jinawath N, Chan DW, Shih IM, Zhang Z, Zhang $\mathrm{H}$ : Quantitative proteomic analysis of ovarian cancer cells identified mitochondrial proteins associated with Paclitaxel resistance. Proteomics Clin Appl 2009, 3:1288-1295.

26. Edge SB, Byrd DR, Compton CC, Fritz AG, Greene FL, Trotti A: AJCC Cancer Staging Manual. 7th edition. New York, NY: Springer; 2010.

27. Travis WD, Brambilla E, Noguchi M, et al: International association for the study of lung cancer/American thoracic society/European respiratory society international multidisciplinary classification of lung adenocarcinoma. J Thorac Oncol. 2011, 6:244-285.

28. Silver SA, Askin FS: True papillary carcinoma of the lung: a distinct cliniclpathologic entity. Am J Surg Pathol 1997, 21:43-51.

29. Li QK, Shah P, Li Y, Aiyetan PO, Chen J, Yung RCW, Molena D, Gabrilson E, Askin F, Chan DW, Zhang H: Glycoproteomic analysis of bronchoalveolar lavage (BAL) fluid identifies tumor-associated glycoproteins from lung adenocarcinoma. J Proteome Res. 2013, 12:3638-3696.

30. Nakamori S, Ota DM, Cleary KR, Shirotani K, Irimura T: MUC1 mucin expression as a marker of progression and metastasis of human colorectal carcinoma. Gastroenterology. 1994, 106:353-361.

31. Lüttges J, Feyerabend B, Buchelt T, Pacena M, Klöppel G: The mucin profile of noninvasive and invasive mucinous cystic neoplasms of the pancreas. Am J Surg Pathol. 2002, 26:466-471.

32. Nitta T, Sugihara K, Tsuyama S, Murata F: Immunohistochemical study of MUC1 mucin in premalignant oral lesions and oral squamous cell carcinoma: association with disease progression, mode of invasion, and lymph node metastasis. Cancer. 2000, 88:245-254.

33. Takao S, Uchikura K, Yonezawa S, Shinchi H, Aikou T: Mucin core protein expression in extrahepatic bile duct carcinoma is associated with metastases to the liver and poor prognosis. Cancer. 1999, 86:1966-1975.

34. Komatsu M, Jepson S, Arango ME, Carothers Carraway CA, Carraway KL: Muc4/sialomucin complex, an intramembrane modulator of ErbB2/HER2/ $\mathrm{Neu}$, potentiates primary tumor growth and suppresses apoptosis in a xenotransplanted tumor. Oncogene. 2001, 20:461-470.

35. Perrais M, Pigny P, Copin MC, Aubert JP, Van Seuningen I: Induction of MUC2 and MUC5AC mucins by factors of the epidermal growth factor (EGF) family is mediated by EGF receptor/Ras/Raf/extracellular signalregulated kinase cascade and Sp1. J Biol Chem. 2002, 277:32258-32267.

36. Copin MC, Buisine MP, Devisme L, Leroy X, Escande F, Gosselin B, Aubert JP, Porchet N: Normal respiratory mucosa, precursor lesions and lung carcinomas: differential expression of human mucin genes. Front Biosci 2001, 6:D1264-1275. Review.

37. Copin MC, Buisine MP, Leteurtre E, Marquette $\mathrm{CH}$, Porte $\mathrm{H}$, Aubert JP, Gosselin B, Porchet N: Mucinous bronchioloalveolar carcinomas display a specific pattern of mucin gene expression among primary lung adenocarcinomas. Hum Pathol. 2001, 32:274-281.

38. MacDermed DM, Khodarev NN, Pitroda SP, Edwards DC, Pelizzari CA, Huang L, Kufe DW, Weichselbaum RR: MUC1-associated proliferation signature predicts outcomes in lung adenocarcinoma patients. BMC Med Genomics. 2010, 3:16.

39. Chen $H$, Suzuki M, Nakamura Y, Ohira M, Ando S, lida T, Nakajima T, Nakagawara A, Kimura $\mathrm{H}$ : Aberrant methylation of FBN2 in human non-small cell lung cancer. Lung Cancer. 2005, 50:43-49.

40. Kukulj S, Jaganjac M, Boranic M, Krizanac S, Santic Z, Poljak-Blazi M: Altered iron metabolism, inflammation, transferrin receptors, and ferritin expression in non-small-cell lung cancer. Med Oncol. 2010, 27:268-277.

41. Oh JE, Krapfenbauer K, Fountoulakis M, Frischer T, Lubec G: Evidence for the existence of hypothetical proteins in human bronchial epithelial, fibroblast, amnion, lymphocyte, mesothelial and kidney cell lines. Amino Acids 2004, 26:8-18.

42. Konicek BW, Stephens JR, McNulty AM, Robichaud N, Peery RB, Dumstorf CA, Dowless MS, Iversen PW, Parsons S, Ellis KE, McCann DJ, Pelletier J, Furic L, Yingling JM, Stancato LF, Sonenberg N, Graff JR: Therapeutic inhibition of MAP kinase interacting kinase blocks eukaryotic initiation factor $4 \mathrm{E}$ phosphorylation and suppresses outgrowth of experimental lung metastases. Cancer Res. 2011, 71:1849-1857.

43. Bortner JD Jr, Das A, Umstead TM, Freeman WM, Somiari R, Aliaga C, et al Down-regulation of 14-3-3 isoforms and annexin $A 5$ proteins in lung adenocarcinoma induced by the tobacco-specific nitrosamine NNK in the A/J mouse revealed by proteomic analysis. J Proteome Res 2009, 8:4050-4061.

44. Boersma HH, Kietselaer BL, Stolk LM, Bennaghmouch A, Hofstra L, Narula J, Heidendal GA, Reutelingsperger CP: Past, present, and future of annexin A5: from protein discovery to clinical applications. J Nucl Med 2005, 46:2035-2050. Review.

45. Fritzsche FR, Dahl E, Dankof A, Burkhardt M, Pahl S, Petersen I, Dietel M, Kristiansen G: Expression of AGR2 in non small cell lung cancer. Histol Histopathol. 2007, 22:703-708.

46. Liu D, Rudland PS, Sibson DR, Platt-Higgins A, Barraclough R: Human homologue of cement gland protein, a novel metastasis inducer associated with breast carcinomas. Cancer Res. 2005, 65:3796-3805.

47. Xu N, Wang YS, Pan WB, Xiao B, Wen YJ, Chen XC, Chen L, Deng HX, You J, Kan B, Fu AF, Li D, Zhao X, Wei YQ: Human alpha-defensin-1 inhibits growth of human lung adenocarcinoma xenograft in nude mice. Mol Cancer Ther. 2008, 7:1588-1597.

48. Kikuchi T, Hassanein M, Amann JM, Liu Q, Slebos RJ, Rahman SM, Kaufman JM, Zhang X, Hoeksema MD, Harris BK, Li M, Shyr Y, Gonzalez AL, Zimmerman LJ, Liebler DC, Massion PP, Carbone DP: In-depth proteomic analysis of nonsmall cell lung cancer to discover molecular targets and candidate biomarkers. Mol Cell Proteomics. 2012, 11:916-32.

doi:10.1186/1559-0275-10-15

Cite this article as: Li et al:: Aberrant Mucin5B expression in lung adenocarcinomas detected by ITRAQ labeling quantitative proteomics and immunohistochemistry. Clinical Proteomics 2013 10:15. 